\title{
Isolation and Partial Characterization of a Temperature-sensitive Mutant of Bacillus subtilis Impaired in the Development of Competence for Genetic Transformation
}

\author{
By H. JOENJE, W. ADMIRAAL AND G. VENEMA \\ Institute of Genetics, University of Groningen, P.O. Box I4, \\ Haren (Gn), The Netherlands
}

(Received 25 January 1973)

\begin{abstract}
SUMMARY
A temperature-sensitive Bacillus subtilis mutant ( $\mathrm{Com}^{\text {ts }} \mathrm{M} 8$ ) has been isolated which is defective in genetic transformation at the restrictive temperature $\left(42{ }^{\circ} \mathrm{C}\right)$. The mutant was selected on the basis of its transforming properties at 42 and $28{ }^{\circ} \mathrm{C}$ on agar plates spread with DNA. During growth at $37{ }^{\circ} \mathrm{C}$ the mutant shows normal development of transformability (competence), whereas at $42{ }^{\circ} \mathrm{C}$ competence is very low or completely absent. At $42{ }^{\circ} \mathrm{C}$ the mutant is not transfectable with DNA from bacteriophage ø29, but susceptible to normal infection with the complete bacteriophage, indicating that the ability to take up exogenous DNA is impaired at this temperature.

In addition to the loss of competence the mutant shows a changed growth pattern at the restrictive temperature: cultures grow initially at the same rate as cultures of the parental strain up to the late exponential phase of growth and then abruptly change over to a much lower growth rate, simultaneously producing shorter cells than the parental strain. From a genetic analysis evidence has been obtained suggesting that the two altered properties of the mutant, loss of competence and a changed growth pattern at $42{ }^{\circ} \mathrm{C}$, are due to the same mutation.

When the mutant is shifted during growth from the restrictive to the permissive temperature, its subsequent pattern of competence development is similar to that displayed by the parental strain after such a shift. Likewise, the response to an opposite shift is also similar in both strains. Only when the mutant is grown continuously at $42{ }^{\circ} \mathrm{C}$, including the overnight incubation period, is the mutant genotype expressed completely.

The results suggest that at $42{ }^{\circ} \mathrm{C}$ the mutant is blocked in a relatively late step in the development of competence.
\end{abstract}

\section{INTRODUCTION}

Bacteria can be genetically transformed by exogenous DNA only after having developed competence (Hayes, I968). Recently, it has been shown by Dooley, Hadden \& Nester (I97I) that, before acquiring competence, Bacillus subtilis cells pass through a precompetent phase starting 90 to $180 \mathrm{~min}$ before the appearance of competence. The precompetent state involves a changed pattern of cellular synthesis, which is characteristic of a low growth rate: a decreased rate of DNA synthesis and a decreasing ratio of ribonucleic acid to protein 
synthesis. Indirect evidence supporting the existence of the precompetent state had been provided previously by Kretschmer (I967, I968, I969).

Several investigators have reported the isolation of non-conditional competence-negative mutants (Young \& Spizizen, r963; Young, Spizizen \& Crawford, I963; Caster, Postel \& Goodgal, 1970; Prozorov, Kalinina \& Schilina, 1971). We set out to isolate temperaturesensitive competence mutants, which are advantageous in that their deficiency can be provoked by changing the experimental conditions. Furthermore, such mutants are well suited for genetic analysis and have the special advantage that the effects of lethal mutations in genes controlling competence can be studied.

This paper describes the isolation procedure for such mutants and a partial characterization of one of them (mutant $\mathrm{Com}^{\text {ts }} \mathrm{M} 8$ ) is presented.

\section{METHODS}

\section{Strains}

Bacteria. The parental Bacillus subtilis strain 3G-I8 carrying three unlinked auxotrophic markers $\operatorname{trp} C_{2}$, pur $A$ and met (tryptophan-, adenine- and methionine-requiring) is a derivative of strain $168 \operatorname{trp} C_{2}$ MARBURG (for the isolation of strain 3G-I8, see Joenje, Gruber \& Venema (1972)).

Bacteriophage. $₫ 29$ was kindly provided by Dr G. A. Wilson (Rochester, New York, U.S.A.).

\section{Media}

WB medium: Spizizen's minimal salts (Spizizen, I958) plus $0.5 \%$ glucose, $50 \mu \mathrm{g} / \mathrm{ml}$ (each) of nine competence-enhancing amino acids (Wilson \& Bott, 1968) which include tryptophan and methionine (all $\mathrm{L}$-isomers), adenine $(20 \mu \mathrm{g} / \mathrm{ml})$ and $2.5 \mathrm{mM}-\mathrm{MgSO}_{4}$. Minimal medium: Spizizen's minimal salts plus $0.5 \%$ glucose. Minimal agar: $\mathrm{I} \cdot 75 \%$ agar (Difco) in Spizizen's minimal salts plus I \% glucose, the growth requirements $(20 \mu \mathrm{g} / \mathrm{ml})$ and amino acids for stimulation of growth (competence-enhancing amino acids to to $50 \mu \mathrm{g} / \mathrm{ml}$ each, or casein hydrolysate $200 \mu \mathrm{g} / \mathrm{ml}$ ). TBAB agar: $3.3 \%$ Tryptose Blood Agar Base (Difco). Top agar for plating ø29 infectious centres: I \% Tryptone (Oxoid), $0.8 \% \mathrm{NaCl}, 0.6 \%$ agar (Difco) and $0.6 \%$ glucose. All media were prepared with glass-distilled water. All chemicals used for the preparation of the media were purchased from BDH Ltd (Poole, Dorset), unless stated otherwise. Pancreatic deoxyribonuclease was from Miles Seravac (PTY) Ltd (Maidenhead, Berkshire).

\section{DNA isolation}

Bacterial DNA was isolated from tryptophan-independent cultures according to a modification of Kirby's procedure (Kirby, I957) as described by Venema, Pritchard \& VenemaSchröder (1965). ø29 DNA was isolated as described previously (Joenje et al. 1972). DNA concentrations were measured by the diphenylamine reaction as described by Burton (I956).

\section{Assay of growth and competence development}

Recipient cultures were grown to competence as follows. An overnight culture in WB medium was diluted into fresh prewarmed WB medium to $\mathrm{I} \times 10^{7}$ to $3 \times 10^{7}$ colony-formers/ $\mathrm{ml}$ (corresponding to an $E_{450}$ of approx. 0.2, see below) and subsequently grown under standard conditions. Where indicated, cultures were started from frozen $\left(-85^{\circ} \mathrm{C}\right) \log$-phase 
bacteria. Growth was followed by measuring the absorbance at $450 \mathrm{~nm}\left(E_{450}\right)$ in a Zeiss Spectrophotometer model PMQ II. At densities higher than I 0 , samples were diluted tenfold before being measured. Development of competence was followed by transforming $0.9 \mathrm{ml}$ samples with 3 to $5 \mu \mathrm{g} / \mathrm{ml} \operatorname{trp} C_{2}{ }^{+}$DNA (in $0.1 \mathrm{ml}$ ) usually during $30 \mathrm{~min}$, unless stated otherwise. Uptake of DNA was terminated by the addition of ro $\mu$ l deoxyribonuclease $(2 \mathrm{mg} / \mathrm{ml})$ in $\mathrm{I} \mathrm{M}-\mathrm{MgSO}_{4}$ and $5 \mathrm{~min}$ additional incubation. Transformants were scored on plates without tryptophan and supplemented with $0.02 \%$ casein hydrolysate. Dilutions were made in minimal medium. Transfectability was measured by exposing bacteria to $20 \mu \mathrm{g} / \mathrm{ml}$ ø29 DNA; transfectants were plated on TBAB plates with $2.5 \mathrm{ml}$ top agar plus about $5 \times 10^{2}$ indicator cells.

\section{Selection of temperature-sensitive competence $\left(\mathrm{Com}^{\mathrm{tg}}\right)$ mutants}

Exponentially growing cultures of $3 \mathrm{G}-\mathrm{I} 8$ in WB medium at $37^{\circ} \mathrm{C}$ were treated for $90 \mathrm{~min}$ with $50 \mu \mathrm{g} N$-methyl- $N^{\prime}$-nitro- $N$-nitrosoguanidine (Aldrich Chemicals Co., Inc. Milwaukee, Wisconsin, U.S.A.)/ml. After washing with minimal medium the bacteria were grown in fresh WB medium during 4 to $5 \mathrm{~h}$ at $37^{\circ} \mathrm{C}$ for mutant segregation. They were then plated on non-selective plates to give Ioo to 200 colonies/plate and incubated at $42{ }^{\circ} \mathrm{C}$. After the colonies had grown to a diameter of I to $\mathrm{I} \cdot 5 \mathrm{~mm}$ each plate was replica-plated on to two plates lacking tryptophan but spread with DNA (approx. $30 \mu \mathrm{g} /$ plate) extracted from $\operatorname{trp} C_{2}{ }^{+}$. One series of replicas was then incubated at $28{ }^{\circ} \mathrm{C}$, the other at $42{ }^{\circ} \mathrm{C}$. After incubation overnight the majority of the colonies had grown on the DNA plates; those colonies growing on the $28{ }^{\circ} \mathrm{C}$ plates but lacking from the $42{ }^{\circ} \mathrm{C}$ plates were picked up from the master plate and assayed for their transformability in liquid medium at 37 and $42{ }^{\circ} \mathrm{C}$. In this way 15 temperature-sensitive transformation-negative mutants were obtained; the majority of the mutants obtained by this method appeared to be of the non-conditional type, when retested in liquid medium. The mutant described in this paper was designated $\mathrm{Com}^{\mathrm{ts}} \mathrm{M} 8$.

\section{RESULTS}

Transformability of $3 \mathrm{G}-\mathrm{I} 8$ relative to $\mathrm{Com}^{\mathrm{ts}} \mathrm{M} 8$ as a function of temperature

To determine the temperature range in which the mutant changes its phenotype we compared the maximum transformation frequencies of $\mathrm{Com}^{\text {ts }} \mathrm{M} 8$ cultures measured during one growth cycle with those of parental cultures at various temperatures between 34 and $42{ }^{\circ} \mathrm{C}$, including the overnight period of growth. Fig. I shows that the temperature range in which the transition from wild-type to mutant phenotype occurs is very narrow. At temperatures in excess of $40^{\circ} \mathrm{C}$ the mutant's transformability is affected drastically, whereas the parental strain is only moderately affected, resulting in a 270 -fold difference. On the basis of these results we chose 37 and $42{ }^{\circ} \mathrm{C}$ as the permissive and restrictive temperatures, respectively.

\section{Effect of temperature during incubation overnight on development of competence}

To assess the effect of temperature during the overnight period of growth on the mutant and parental phenotype, overnight cultures of both $3 \mathrm{G}-\mathrm{I} 8$ and $\mathrm{Com}^{\text {ts }} \mathrm{M} 8$ were grown at $37^{\circ} \mathrm{C}$ and at $42{ }^{\circ} \mathrm{C}$ and after dilution into fresh medium cultured at $37^{\circ} \mathrm{C}$ as well as at $42^{\circ} \mathrm{C}$. Fig. 2, in which only the peaks of competence have been presented, shows that the mutant's transformability at $37{ }^{\circ} \mathrm{C}$ following overnight growth at $42{ }^{\circ} \mathrm{C}$ is almost the same as that of the parental strain. This level of competence is equal to the level reached at $37^{\circ} \mathrm{C}$ following overnight growth at $37{ }^{\circ} \mathrm{C}$ (not shown in Fig. 2). In the reverse case, growth overnight at 


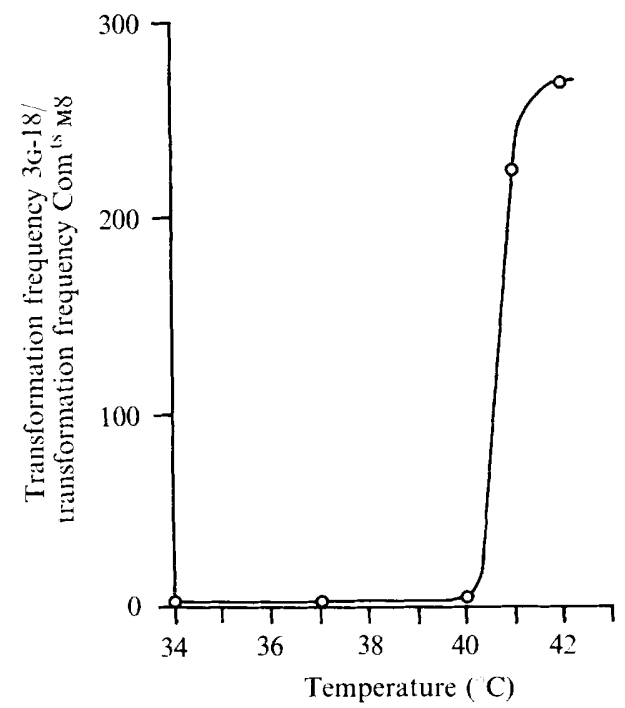

Fig. I. Transformability of $3 \mathrm{G}-\mathrm{I} 8$ relative to $\mathrm{Com}^{\mathrm{ts}} \mathrm{M} 8$ as a function of temperature. Maximum transformation frequencies of $3 \mathrm{G}-18$ and $\mathrm{Com}^{\mathrm{ts}} \mathrm{M} 8$ were determined during one growth cycle at various temperatures in the interval 34 to $42{ }^{\circ} \mathrm{C}$. Overnight cultures were incubated at the corresponding temperatures. The ordinate values represent the ratio of the maximal transformation frequency of $3 \mathrm{G}-18$ to that of $\mathrm{Com}^{\mathrm{ts}} \mathrm{M} 8$ determined at various temperatures.

$37^{\circ} \mathrm{C}$ followed by growth at $42^{\circ} \mathrm{C}$, the mutant transforms Io times less well than strain 3G-I 8 . The mutant's transformability is almost completely suppressed if subjected to the competence regimen at $42{ }^{\circ} \mathrm{C}$ following previous growth also at $42{ }^{\circ} \mathrm{C}$. Additionally, in this experiment the mutant appears to develop its (poor) wave of competence at a later time than the parental strain. The figure also shows that the parental strain is less transformable at the elevated temperature than at $37^{\circ} \mathrm{C}$. However, transformability of $\mathrm{Com}^{\text {ts }} \mathrm{M} 8$ cells is much more drastically affected.

\section{Competence for transformation and 029 transfection}

To establish whether the Com ${ }^{\text {ts }} \mathrm{M} 8$ mutant is blocked in the uptake of donor DNA or in its ability to integrate the DNA, we tested the mutant's capability of propagating phage progeny upon incubation with infectious DNA from bacteriophage ø29. This test seems to be unambiguous since $ø 29$ transfection has been shown to be independent of the host's recombinational system (Spatz \& Trautner, 1971). Fig. 3 shows that at the restrictive temperature the transfecting activity of ø29 DNA is also strongly reduced in the mutant when compared to that in strain $3 \mathrm{G}-\mathrm{I} 8$. Since $\mathrm{Com}^{\text {ts }} \mathrm{M} 8$ produces normal amounts of phage progeny following infection with ø29 particles at the restrictive temperature (results not shown), we conclude that the mutant is not transformed at $42{ }^{\circ} \mathrm{C}$ because it is unable to take up the DNA. This experiment does not exclude the possibility that the mutant has an additional defect in its recombinational system; however, this seems unlikely since we have strong evidence (see below) that the transformation-deficiency is due to only one mutation.

\section{Development of competence in relation to growth}

Fig. 4 shows the growth and competence development of the parental and the mutant strains at 42 and $37^{\circ} \mathrm{C}$. Compared with $3 \mathrm{G}-\mathrm{I} 8$ the mutant shows a normal growth pattern at 


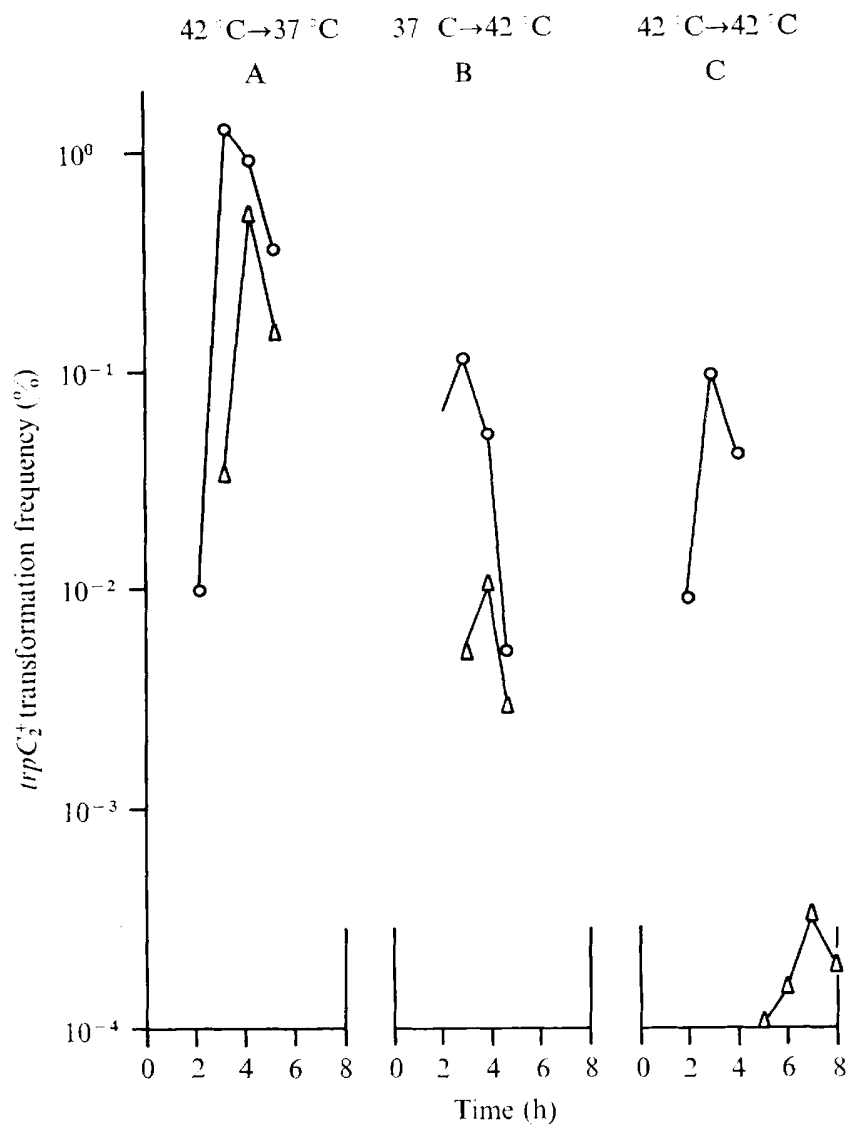

Fig. 2. Effect of temperature during overnight incubation on competence development of $3 \mathrm{G}-\mathrm{I} 8$ and $\mathrm{Com}^{\text {ts }} \mathrm{M} 8$. Overnight cultures of $3 \mathrm{G}-\mathrm{I} 8$ and $\mathrm{Com}^{\mathrm{ts}} \mathrm{M} 8$ were grown at $42{ }^{\circ} \mathrm{C}$ (A and C) or at $37^{\circ} \mathrm{C}$ (B) in WB medium and diluted into fresh medium. Transformability was assayed during subsequent growth at $42{ }^{\circ} \mathrm{C}$ (B and $\mathrm{C}$ ) or $37^{\circ} \mathrm{C}(\mathrm{A})$ by transforming samples at hourly intervals (see Methods). Only peaks of transformability are shown. $\mathrm{O}-\mathrm{O}, 3 \mathrm{G}-\mathrm{I} 8 ; \triangle-\triangle \mathrm{Com}^{\mathrm{ts}} \mathrm{M} 8$. In this and subsequent Figures the times indicated refer to the addition of donor DNA.

$37^{\circ} \mathrm{C}$ and also develops a normal (even higher) level of competence. At $42{ }^{\circ} \mathrm{C}$, however, together with the loss of transformability, the mutant shows a changed growth pattern: at the end of the exponential phase of growth the growth rate decreases abruptly and becomes almost zero. Light microscopic examination of the mutant and parental bacteria at various times during growth shows a significant difference in bacterial length in samples taken after the interruption in the growth curve of the mutant has occurred. Com ${ }^{\text {ts }} \mathrm{M} 8$ bacteria appear to be shorter than the parental bacteria, especially during the postexponential phase (see Fig. 5). In addition, the length of $\mathrm{Com}^{\text {ts }} \mathrm{M} 8$ bacteria appears, from the standard deviations, to be less variable.

\section{Number of mutations involved in the Com ${ }^{\mathrm{ts}} \mathrm{M} 8$ phenotype}

For further analysis of the mutant it was essential to know whether the loss of competence and the changed growth pattern were due to the same or to different mutations. To examine this, we made use of the finding that mutant bacteria, as a result of their depressed growth 


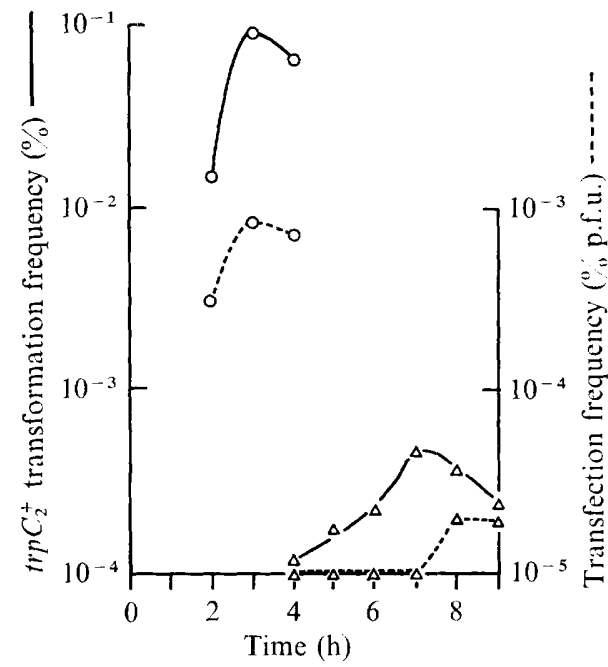

Fig. 3

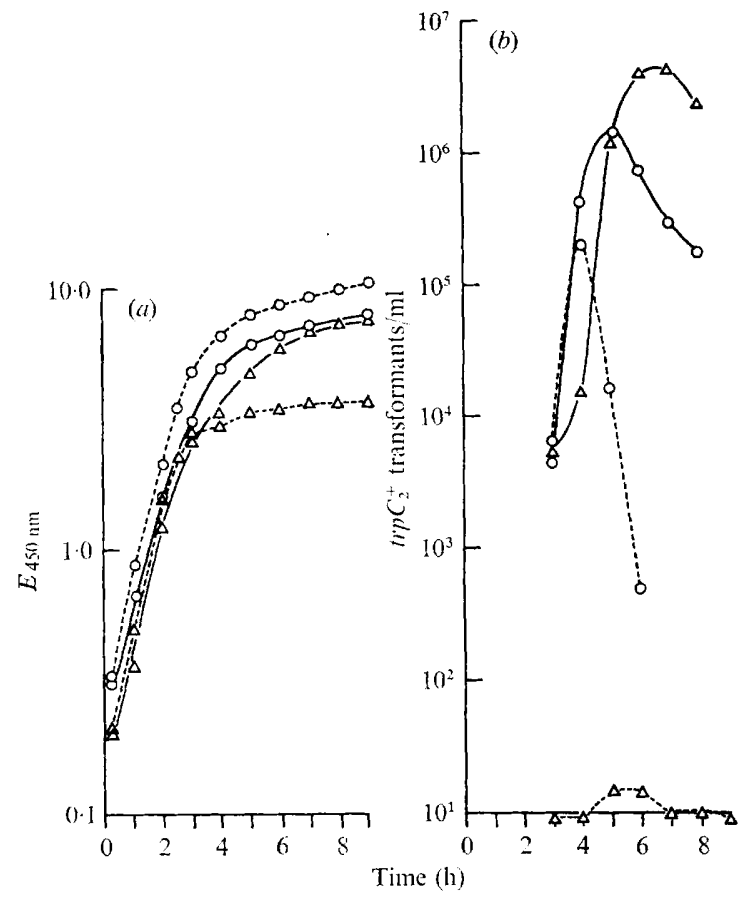

Fig. 4

Fig. 3. Transformability and transfectability of $3 \mathrm{G}-\mathrm{I} 8$ and $\operatorname{Com}^{\mathrm{ts}} \mathrm{M} 8$ as a function of growth time at $42^{\circ} \mathrm{C}$. Overnight $42^{\circ} \mathrm{C}$ cultures of both strains were diluted at time zero into fresh medium prewarmed to $42{ }^{\circ} \mathrm{C}$ and grown at $42{ }^{\circ} \mathrm{C}$. Transformability and transfectability were assayed as described in Methods. -..--, Transfection frequency (\%plaque-forming units); _ frequency ( $\% \operatorname{trp}_{2}{ }^{+}$transformants). $\mathrm{O}, 3 \mathrm{G}-\mathrm{I} 8 ; \triangle, \mathrm{Com}^{\mathrm{ts}} \mathrm{M} 8$.

Fig. 4. Growth and competence development of $3 \mathrm{G}-\mathrm{I} 8$ and $\mathrm{Com}^{\mathrm{ts}} \mathrm{M} 8$ at $37^{\circ} \mathrm{C}$ and $42{ }^{\circ} \mathrm{C}$. Frozen $42{ }^{\circ} \mathrm{C}-\log$ phase cells of $3 \mathrm{G}-\mathrm{I} 8$ and $\mathrm{Com}^{\mathrm{ts}} \mathrm{M} 8$ were quickly thawed and diluted at time zero into fresh media at $37^{\circ} \mathrm{C}(-)$ and $42^{\circ} \mathrm{C}(---)$. Growth $(a)$ and competence development $(b)$ were determined as described in Methods. $0,3 \mathrm{G}-\mathrm{I} 8 ; \triangle, \mathrm{Com}^{\text {ts }} \mathrm{M} 8$.

rate after the exponential phase of growth, form smaller colonies than the parental bacteria on agar plates incubated at $42^{\circ} \mathrm{C}$. Com ${ }^{\text {ts }} \mathrm{M} 8$ bacteria were made competent at $37{ }^{\circ} \mathrm{C}$ and transformed during $30 \mathrm{~min}$ with a saturating concentration of DNA extracted from the prototrophic wild-type strain. After allowing segregation for $4 \mathrm{~h}$ the bacteria were spread on plates selective for $\mathrm{met}^{+}$transformants and incubated at $42{ }^{\circ} \mathrm{C}$. In the population of $\mathrm{met}^{+}$colonies we determined the frequency of cotransformation for the $\operatorname{trp} C_{2}{ }^{+}$marker and the frequency of large colonies. These two frequencies appeared to be equal (Table I). Apparently, the probability of incorporating the $\operatorname{trp} C_{2}{ }^{+}$marker is equal to the probability of incorporating the property determining wild-type growth, indicating that the changed growth pattern of the mutant is caused by one mutation. Because the frequency of large colonies within the population of $\operatorname{trpC}_{2}{ }^{+} \mathrm{met}^{+}$colonies is roughly equal to the frequency in the total $\mathrm{met}^{+}$ population, it is concluded that the growth pattern-mutation is not linked to the $\operatorname{trp} C_{2}$ marker. Ten large $\mathrm{met}^{+}$colonies were tested in liquid medium and all appeared to have recovered their ability to develop competence at $42{ }^{\circ} \mathrm{C}$. Ten small colonies tested similarly continued to show the mutant phenotype. This favours the conclusion that one mutation is involved causing both the changed growth pattern and the loss of transformability at 

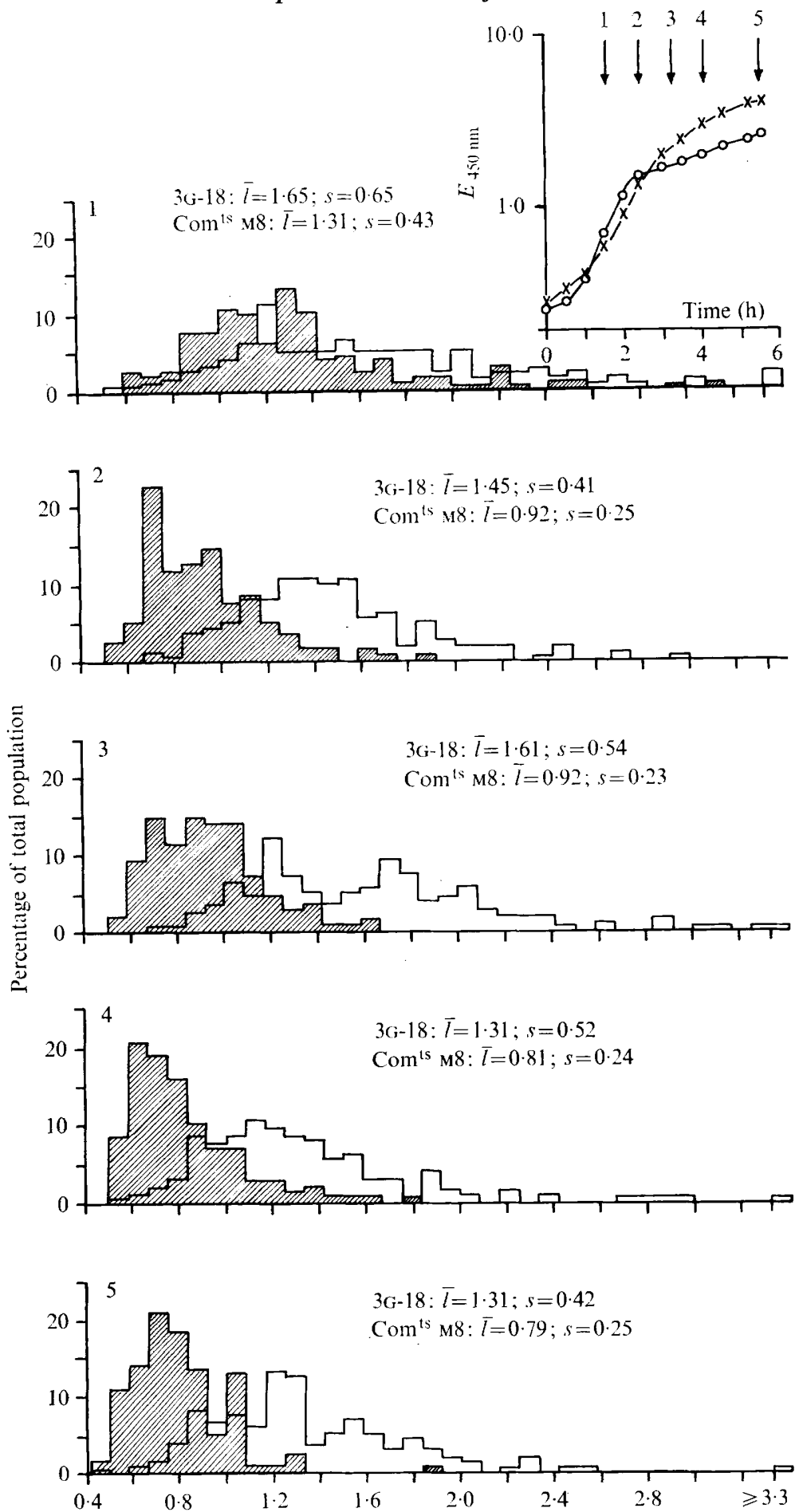

Cell length $(\mu \mathrm{m})$

Fig. 5. Distribution of cell lengths of $3 \mathrm{G}-\mathrm{I} 8$ and $\mathrm{Com}^{\text {ts }} \mathrm{M} 8$ as a function of growth time at $42^{\circ} \mathrm{C}$. Overnight $42{ }^{\circ} \mathrm{C}$ cultures of $3 \mathrm{G}-\mathrm{I} 8$ and $\mathrm{Com}^{\text {ts }} \mathrm{M} 8$ were diluted into fresh medium and grown at $42^{\circ} \mathrm{C}$ (inset: growth of $3 \mathrm{G}-18, \times-\times$; and of $\mathrm{Com}^{\mathrm{ts}} \mathrm{M} 8, \mathrm{O}-\mathrm{O}$ ). The arrows indicate the times when samples were removed (I to 5), concentrated by centrifugation and frozen at $-85^{\circ} \mathrm{C}$. For phasecontrast microscopic examination the samples were quickly thawed and a few drops were spread on glass slides with a thin layer of minimal agar previously dried at $37^{\circ} \mathrm{C}$ for $45 \mathrm{~min}$ to prevent motion of the bacteria. Lengths of $\mathrm{I} 20$ to 200 bacteria per sample were measured from photographs (the final magnification was $6000 \times$ ). 3G-I 8: open, Com ${ }^{\text {ts }} \mathrm{M} 8$ : hatched histogram. The mean cell lengths $(\bar{l})$ and the standard deviations $(s)$ for each sample are shown. 


\section{Table I. Number of mutations involved in $\mathrm{Com}^{\text {ts }} \mathrm{M} 8$ phenotype}

$\mathrm{Com}^{\text {ts }} \mathrm{M} 8$, made competent at $37^{\circ} \mathrm{C}$, was transformed with DNA from a prototrophic wild-type strain and spread on plates without methionine after $5 \mathrm{~h}$ of segregation at $37^{\circ} \mathrm{C}$. Within the popula tion of $\mathrm{met}^{+}$colonies the frequency of large colonies was determined as well as the frequency of colonies being transformed for the $\operatorname{trp} \mathrm{C}_{2}{ }^{+}$marker (by replica-plating).

$\begin{array}{ccccc}\text { Experiment } & \begin{array}{c}\text { Number of } \mathrm{met}^{+} \\ \text {colonies screened }\end{array} & \begin{array}{c}\text { Frequency of } \\ \text { large colonies } \\ (\% \text { of total) }\end{array} & \begin{array}{c}\text { Frequency of } \\ \operatorname{trp} C_{2}^{+} \text {colonies } \\ (\% \text { of total) }\end{array} & \begin{array}{c}\text { Frequency of large } \\ \text { trp } C_{2}^{+} \text {colonies } \\ \left(\% \text { of total } t r p C_{2}^{+}\right. \\ \text {population })\end{array} \\ 1 & 2689 & 6.8 & 7.0 & 9 \\ 2 & 1675 & 4.7 & 4.7 & \text { not assayed }\end{array}$
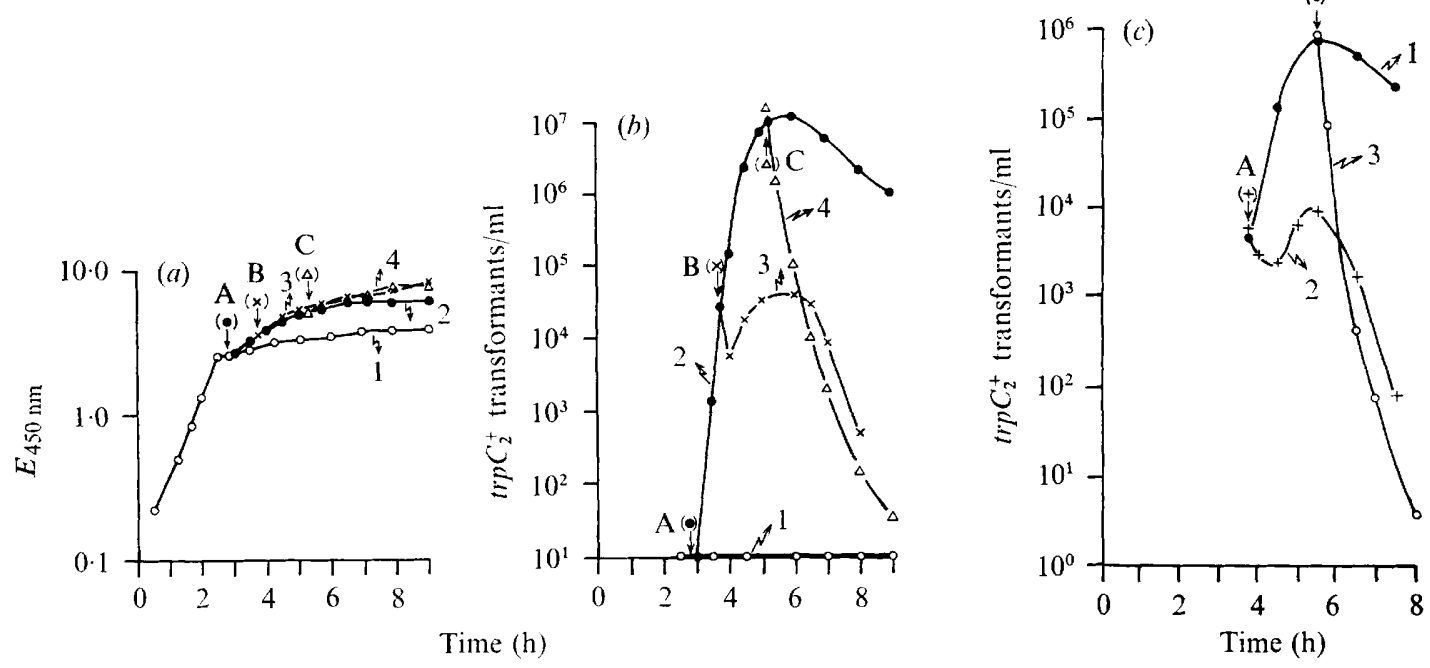

Fig. $6(a),(b)$. Effect of temperature shifts on growth and competence development of $\mathrm{Com}^{\mathrm{ts}} \mathrm{M} 8$. Frozen $42{ }^{\circ} \mathrm{C}-\log$ phase cells of $\mathrm{Com}^{\mathrm{ts}} \mathrm{M} 8$ were quickly thawed and diluted into fresh medium, whereafter growth $(a)$ and competence development $(b)$ were followed at $42^{\circ} \mathrm{C}$ (culture $\mathrm{I}, \mathrm{O}-\mathrm{O}$ ). Shortly after the exponential phase of growth had ended part of the culture was shifted to $37^{\circ} \mathrm{C}$ (indicated by arrow $\mathrm{A}$; culture 2 ). At two times, indicated by the arrows $\mathrm{B}$ and $\mathrm{C}$, part of culture 2 was shifted back to $42^{\circ} \mathrm{C}$ (cultures 3 and 4 , respectively). Growth and competence development of all four cultures were followed $(\mathrm{I}, \mathrm{O}-\mathrm{O} ; 2,->3, \times-\times ; 4, \Delta-\Delta)$. Samples were transformed for $\mathrm{I} 5 \mathrm{~min}$ followed by $5 \mathrm{~min}$ of incubation with deoxyribonuclease before plating.

Fig. $6(\mathrm{c})$. Effect of temperature shifts on competence development of 3G-18. Competence development of strain $3 \mathrm{G}-\mathrm{I} 8$ was followed during growth at $37^{\circ} \mathrm{C}$ (culture $\mathrm{I},-0$ ). At the times indicated by the arrows $\mathrm{A}$ and $\mathrm{B}$ a part of culture I was shifted to $42{ }^{\circ} \mathrm{C}$ (cultures $2,+\cdots+$, and $3,0-\mathrm{O}$, respectively). Competence development was followed by transforming samples during $15 \mathrm{~min}$ followed by $5 \mathrm{~min}$ of incubation with deoxyribonuclease.

$42^{\circ} \mathrm{C}$, although the possibility of two very closely linked mutations cannot be excluded entirely.

\section{Effect of shifting the temperature on development of competence}

In the second paragraph of the Results section we showed that overnight incubation of $\mathrm{Com}^{\text {ts }} \mathrm{M} 8$ at the permissive temperature permits partial expression of the wild-type phenotype during the subsequent growth cycle at the non-permissive temperature. In the following experiments the effect of shifting the temperature during the postovernight incubation period on competence development in both the mutant and the parental strain was studied. 

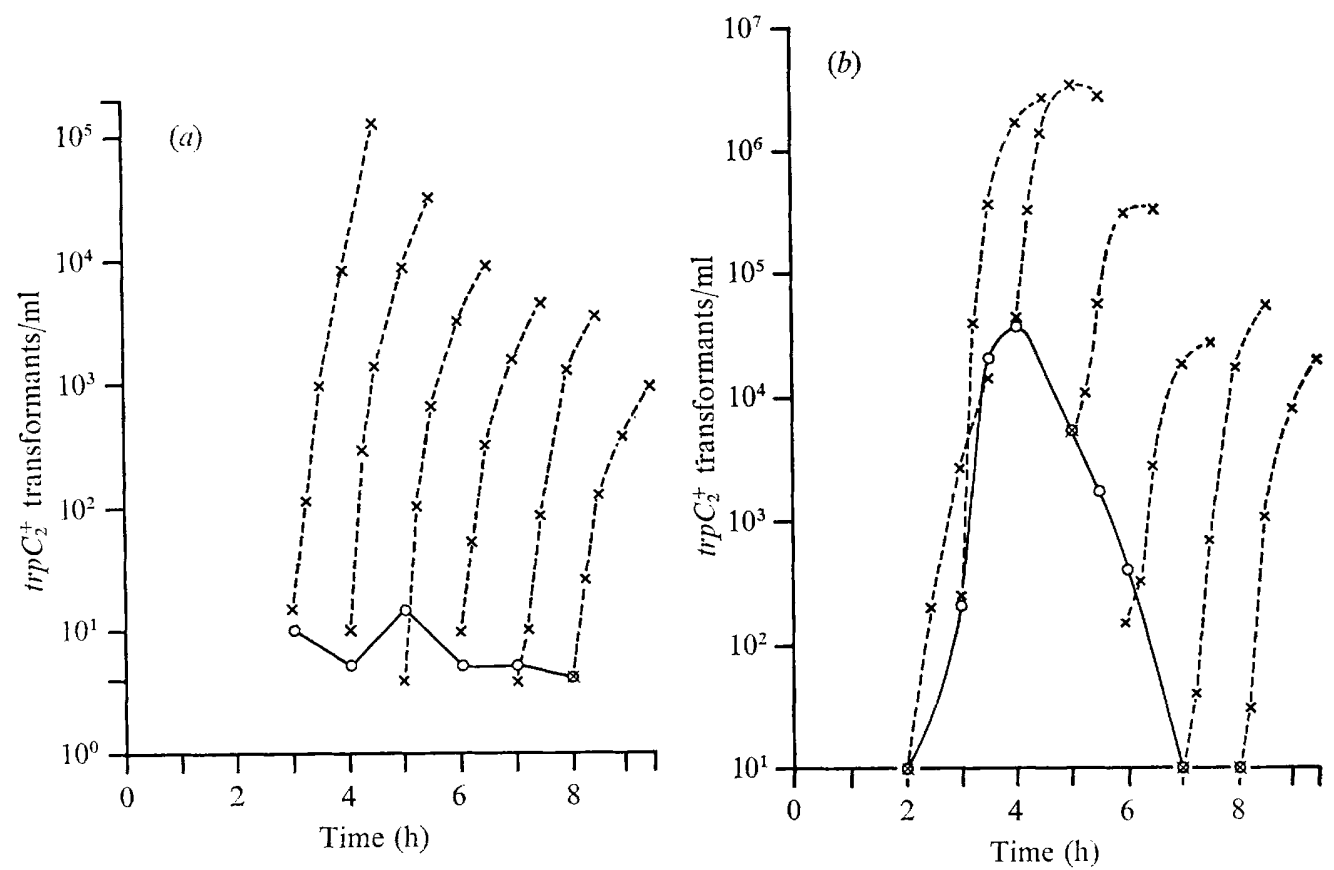

Fig. 7 (a). Response of $\mathrm{Com}^{\mathrm{ts}} \mathrm{M} 8$ to a temperature shift to $37{ }^{\circ} \mathrm{C}$ as a function of growth time at $42^{\circ} \mathrm{C}$. An overnight $42{ }^{\circ} \mathrm{C}$ culture of $\mathrm{Com}^{\text {ts }} \mathrm{M} 8$ was diluted into fresh medium to an $\mathrm{E}_{450}$ of $0 \cdot 3$, after which competence development at $42{ }^{\circ} \mathrm{C}$ was followed $(\mathrm{O}-\mathrm{O})$. At hourly intervals, starting $3 \mathrm{~h}$ after dilution of the overnight culture, parts of the culture were shifted to $37^{\circ} \mathrm{C}$ and competence development in these cultures was followed during $90 \mathrm{~min}(x--\times)$. The time of exposure to DNA was $15 \mathrm{~min}$.

Fig. 7 (b). Response of $3 \mathrm{G}-\mathrm{I} 8$ to a temperature shift to $37^{\circ} \mathrm{C}$ as a function of growth time at $42^{\circ} \mathrm{C}$. The conditions in this experiment were the same as described for Fig. $7(a)$. $\bigcirc-\bigcirc$, Competence development during growth at $42{ }^{\circ} \mathrm{C} ; \times-\times$, competence development at $37^{\circ} \mathrm{C}$.

Fig. $6 a, b$ shows the effect on growth and competence development of shifting a Com ${ }^{\text {ts }} \mathrm{M} 8$ culture from the restrictive temperature at the time when the interruption in its growth curve had occurred to the permissive temperature. It can be seen that the culture responds with reinitiation of growth and an explosive development of competence. When the culture is shifted back to the restrictive temperature during its shift-induced development of competence further progress of competence development is prevented; only a relatively poor wave of competence is observed. If the culture is shifted back at the time when the peak of competence has been reached, a rapid loss of competence is observed. The parental strain, different from the mutant in being able to develop competence when cultured continuously at $42{ }^{\circ} \mathrm{C}$, behaves in exactly the same way, responding with very rapid development of competence when shifted from 42 to $37^{\circ} \mathrm{C}$, displaying only a poor wave of competence when shifted from 37 to $42{ }^{\circ} \mathrm{C}$ during its development of competence, and rapidly loosing competence when shifted from 37 to $42{ }^{\circ} \mathrm{C}$ at the time when maximal competence is achieved (Fig. $6 c, 7 b$ ). Since the mutant culture after being shifted back to the restrictive temperature develops competence characteristic for the parental strain after such a shift, it follows that the relatively short stay at the permissive temperature $(56 \mathrm{~min})$ suffices the mutant to obtain the wild-type phenotype at the restrictive temperature. This also applies to the postexponential growth behaviour of the mutant: as can be seen from Fig. $6 a$, shifting back the mutant to the restrictive temperature results in the continuation of the shift-induced resumption of growth. 
The rapid manifestation of competence in the $\mathrm{Com}^{\text {ts }} \mathrm{M} 8$ bacteria following a shift from 42 to $37^{\circ} \mathrm{C}$ strongly suggests that the mutant is blocked in a relatively late step in its development towards competence. To establish whether the mutant persists in this (precompetent) state at $42{ }^{\circ} \mathrm{C}$ during the full length of the incubation period, or whether this state is transiently acquired, the capacity of cultures growing at $42{ }^{\circ} \mathrm{C}$ to develop competence during a fixed period of time following a shift to $37^{\circ} \mathrm{C}$ was followed as a function of growth time. For comparison, the parental strain was treated similarly. Fig. $7 a$ shows that the number of transformable cells produced by the mutant during a fixed period of exposure to $37^{\circ} \mathrm{C}$ is decreasing as a function of time of growth at $42{ }^{\circ} \mathrm{C}$, indicating that the precompetent state is transiently acquired by the mutant culture at $42^{\circ} \mathrm{C}$. Fig. $7(b)$ shows that during the whole period of competence development at $42{ }^{\circ} \mathrm{C}$ competence in the parental strain is enhanced by a shift to $37^{\circ} \mathrm{C}$, indicating that in the parental strain also, part of the precompetent fraction cannot pass on to the competent state at $42{ }^{\circ} \mathrm{C}$. Even after the parental culture has passed its period of competence at $42{ }^{\circ} \mathrm{C}$, the appearance of new competent cells can still be induced by transfer to $37^{\circ} \mathrm{C}$. In both the mutant and the parental strain the presence of a temperature-inducible competence potency seems to be transient. These results suggest that the characteristic difference between the parental and the mutant strain consists of the complete inability of the precompetent mutant bacteria to pass into the competent state at $42{ }^{\circ} \mathrm{C}$, whereas the parental strain is partly able to do so.

\section{DISCUSSION}

The results of experiments to characterize the $\mathrm{Com}^{\text {ts }}$ mutant indicate that the mutant is unable to become transformed at the restrictive temperature because it is unable to take up exogenous DNA. The mutation causing this defect is pleiotropic: under the non-permissive conditions an aberration in the post-exponential growth phase also occurs. This implies that at least one step in the development of competence is dependent on a gene product that simultaneously controls post-exponential growth.

Shifting the mutant culture from the non-permissive to the permissive temperature and vice versa rapidly results in a change of competence development identical to that observed in the parental strain after such shifts. Furthermore, a relatively short time of exposure to the permissive temperature after growth at the restrictive temperature enables the mutant culture to acquire its wild-type phenotype at the restrictive temperature (Fig. 6).

Recent studies by Dooley et al. (I97I) have led to the recognition of the precompetent state through which a cell must pass before the acquisition of the transformable state. Since they found that the precompetent phase precedes the competent state by 90 to $180 \mathrm{~min}$, the rapid appearance of transformable mutant bacteria upon shifting the temperature from the restrictive to the permissive one (Fig. $6 b$ ) indicates that the bacteria have already developed precompetence at the time of the shift. Although able to develop a fair degree of competence when continuously cultured at $42{ }^{\circ} \mathrm{C}$, the parental strain also rapidly responds to a shift in temperature to $37^{\circ} \mathrm{C}$, inferring that in $42{ }^{\circ} \mathrm{C}$ cultures many of the parental bacteria also fail to pass from the precompetent to the competent state. Since the precompetent state seems to be transiently acquired at this temperature, it is concluded that the transience of the competent state is governed by that of the precompetent phase. The characteristic difference between the two strains apparently consists of the partial ability of the precompetent bacteria of the parental strain to pass on to the competent state at $42{ }^{\circ} \mathrm{C}$, whereas the mutant precompetent bacteria are completely unable to do so.

The inability of the mutant to take up exogenous DNA and its changed cell morphology 
observed at the restrictive temperature (Fig. 5) suggest that the mutant has an altered cell envelope. However, a significant difference between the two strains in their sensitivity to deoxycholate, EDTA, lysozyme or osmotic shock could not be established; in addition electron-microscopic examination of bacteria at various times during growth did not reveal distinct differences in their general appearance or in their components.

Recently we reported that Bacillus subtilis cultures excrete competence-stimulating activity into the culture fluids; this activity causes an earlier initiation of competence development when physiologically low-competent cultures are exposed to such culture fluids (Joenje et al. 1972). Mutant $\mathrm{Com}^{\text {ts }} \mathrm{M} 8$ was found to produce competence stimulating activity at $42{ }^{\circ} \mathrm{C}$ (unpublished results) but is apparently not able to respond to it.

The authors are indebted to Dr C. A. Vermeulen and Mr M. Veenhuis for making many electron-micrographs, and to Professor Dr Ir. W. J. Feenstra and Professor Dr M. Gruber for critical reading of the manuscript. This work was carried out under the auspices of the Netherlands Foundation for Chemical Research (S.O.N.) and with financial aid from the Netherlands Organization for the Advancement of Pure Research (Z.W.O.).

\section{REFERENCES}

Burton, K. (1956). A study of the conditions and mechanism of the diphenylamine reaction for the colorimetric estimation of deoxyribonucleic acid. Biochemical Journal 62, 315-323.

Caster, J. H., Postel, E. H. \& Goodgal, S. H. (I970). Competence mutants: isolation of transformation deficient strains of Haemophilus influenzae. Nature, London 227, 515-517.

Dooley, D. C., HadDen, C. T. \& Nester, E. W. (1971). Macromolecular synthesis in Bacillus subtilis during development of the competent state. Journal of Bacteriology I08, 668-679.

HAYES, W. (1968). The Genetics of Bacteria and Their Viruses, 2nd edn., p. 583. Oxford: Blackwell Scientific Publications.

Joenje, H., Gruber, M. \& Venema, G. (I972). Stimulation of the development of competence by culture fluids in Bacillus subtilis transformation. Biochimica et biophysica acta 262, I89-199.

KIRBY, K. S. (1957). A new method for the isolation of deoxyribonucleic acids: evidence on the nature of bonds between deoxyribonucleic acid and protein. Biochemical Journal 66, 495-504.

KretsChmer, S. (1967). Ausbildung von Kompetenz für genetische Transformation in Bacillus subtilis Zellen nach Uebergang in den Ruhezustand. Zeitschrift für Allgemeine Mikrobiologie 7, 235-237.

KRETSCHMER, S. (1968). Empfindlichkeit der Kompetenzentwicklung gegenüber Störungen des steady state bei der genetischen Transformation von Bacillus subtilis. Zeitschrift für Allgemeine Mikrobiologie 8, 19-28.

KretsChmer, S. (1969). Kompetenzdauer von Bacillus subtilis Zellen. Zeitschrift für Allgemeine Mikrobiologie 9, 457-470.

Prozorov, A. A., Kalinina, N. A. \& Schilina, V. N. (197I). Study of Bacillus subtilis mutants with changed competence. Genetika 7, 83-93.

Spatz, H. Ch. \& Trautner, T. A. (197I). The role of recombination in transfection of $B$. subtilis. Molecular and General Genetics II3, I 74-190.

SPIZIZEN, J. (1958). Transformation of biochemically deficient strains of Bacillus subtilis by deoxyribonucleate. Proceedings of the National Academy of Sciences of the United States of America 44, 1072-1078.

Venema, G., Pritchard, R. H. \& Venema-Schröder, T. (I965). Fate of transforming deoxyribonucleic acid in Bacillus subtilis. Journal of Bacteriology 89, $1250-1255$.

WiLson, G. A. \& Botт, K. F. (1968). Nutritional factors influencing the development of competence in the Bacillus subtilis transformation system. Journal of Bacteriology, 95, I439-I449.

Young, F. E., Spizizen, J. \& Crawford, I. P. (1963). Biochemical aspects of competence in the Bacillus subtilis transformation system. I. Chemical composition of cell walls. Journal of Biological Chemistry 238, 3119-3I25.

YounG, F. E. \& SPIZIZEN, J. (1963). Biochemical aspects of competence in the Bacillus subtilis transformation system. Journal of Biological Chemistry 238, 3126-31 30. 